\title{
Study on Bond Strength of Bonded Gray Cast Iron
}

\author{
Awfa Abdul-Rassol Abdullah and Rasha Rahman Rawhdan* \\ Department of Applied Science, Material Branch, University of Technology, Baghdad-Iraq. \\ "E-mail: rasha_medical1986@ymail.com.
}

\begin{abstract}
In the present study, two gray cast iron specimens were diffusion bonded at the temperatures of $700,750,800,850$, and $900{ }^{\circ} \mathrm{C}$, the furnace used atmosphericexperiment under a pressing load of 1 and 2 ton for 15, 30 and 60min. After diffusion bonding, shear test measurements of interface region were made. As a result, from the microstructural observations, a good bonding along the interface of the bonded couples were detected since the interface is free from voids and microcracks. To evaluate the bond strength, the shear test investigation was used. The actual bonded area was calculated by using a computer package called (Auto Cad 2006). The results shows that the bond strength increases with increasing the temperature and holding time. Fracturography of the interface was carried out by using optical microscope before and after the experiments. The microstructure results shows the formation of carbide. Its precipitation increases with increasing the bonding temperature and time.
\end{abstract}

Keywords: Diffusion bonding, Gray Cast Iron, Shear Strength.

\section{Introduction}

Diffusion bonding is a joining process in which two nominally flat surfaces are held together, under applied pressing load at an elevated temperature typically above $0.6 \mathrm{~T}_{\mathrm{m}}$ (melting temperature) for a period of time until a bond is formed. This process is relatively simply when two identical materials are to be joined, but when joining dissimilar materials, there are many potential complications. Solid state bonding of metals has a long history; it was one of the joining technologies developed by Kazakov [1]. Diffusion bonding developed as an alternative joining technology has proved successful in the production of diverse compound parts of various metallic alloys [2].

The diffusion bonding process consists of three stages. At the first stage, the contact area increases by localized deformation and creep. At the second stage, diffusion takes place at the contact area and eliminates the voids at the original grain interface. Finally, the grain boundaries on the interface migrate and grain growth occurs [3].

The diffusion bonding process parameters including bonding temperature, holding time and pressure are key factors in interfacial structures, compound formation and bonding strength of the joints [4].
Almost all materials with compatible chemical and metallurgical properties can be joined by the diffusion bonding process. This welding process has an inherent advantage over conventional welding because it does not involve the formation of unexpected phases at the bond interface that may occur in some advanced materials. The crack, distortion and segregation produced using fusion welding can be avoided using diffusion bonding technology [5].

Gray cast irons are in essence iron-carbonsilicon alloys containing small quantities of other elements. The metallurgy of gray cast irons are extremely complex because of a wide variety of factors that influence their solidification and subsequent solid-state transformations. In spite of this complexity, gray irons have found wide acceptance based on a combination of outstanding castability, excellent machinability, economics, and unique properties. However, cast iron is known as a hardly welding material. The poor weldability of cast iron can be attributed to two factors: the formation of martensite in the heat affected zone (HAZ), and the development of hard, brittle iron carbide in the zone of partial fusion [6]. 


\section{Material and Method \\ Material}

In this study, two gray cast iron specimens were diffusion bonded. Table 1shows the chemical compositions of this material where the type of gray cast iron is G2 class 40, Melting point of gray cast iron ranging from 1150 to $1200{ }^{\circ} \mathrm{C}$ [7].

Table (1)

The chemical composition of gray cast iron specimen.

\begin{tabular}{|c||c||c|c||c|c||c||c||c|c||c|c||c||c|}
\hline $\begin{array}{c}C \\
(\%)\end{array}$ & $\begin{array}{c}S i \\
(\%)\end{array}$ & $\begin{array}{c}M n \\
(\%)\end{array}$ & $\begin{array}{c}C r \\
(\%)\end{array}$ & $\begin{array}{c}\text { Ni } \\
(\%)\end{array}$ & $\begin{array}{c}M o \\
(\%)\end{array}$ & $\begin{array}{c}A l \\
(\%)\end{array}$ & $\begin{array}{c}C u \\
(\%)\end{array}$ & $\begin{array}{c}C o \\
(\%)\end{array}$ & $\begin{array}{c}T i \\
(\%)\end{array}$ & $\begin{array}{c}N b \\
(\%)\end{array}$ & $\begin{array}{c}V \\
(\%)\end{array}$ & $\begin{array}{c}W \\
(\%)\end{array}$ & $\begin{array}{c}F e \\
(\%)\end{array}$ \\
\hline \hline$\leq 2.64$ & 2.72 & 0.661 & 0.397 & 0.25 & 0.082 & 0.07 & 0.361 & $<0.05$ & $<0.05$ & $<0.05$ & 0.05 & 0.05 & 92.3 \\
\hline
\end{tabular}

\section{Method}

Diffusion bonding samples were performed using the gray cast iron, with dimensions, $20 \mathrm{~mm} \times 20 \mathrm{~mm} \times 18 \mathrm{~mm}$, by using hydraulic cutting machine and subjected to grinding and polishing before attempted the diffusion bonding experiment. Diffusion bonds were produced in atmospheric furnace which the couples were subjected to pressing load of 1 and 2 ton at temperatures of 700, 750, 800,850 , and $900^{\circ} \mathrm{C}$. Once the bonding process was completed, thesamples cooled in atmospheric furnace to room temperature. All samples were fixed by using suitable fixtures made of plates from high temperature resistance material Inconel $600 \quad(5 \mathrm{~mm}$ thickness, $100 \mathrm{~mm}$ length, $1.5 \mathrm{~mm}$ width). Itis were used to transfer the load to the samples by using the compression machine as shown in Fig.(1), which represents a certain type of equipment utilized for solid state bonding experiments. The bondedspecimens were further machined to produce shear test specimens. AnInstron tensile testing machine set at a crosshead speed of $1 \mathrm{~mm} /$ minwas used for the shear tests.

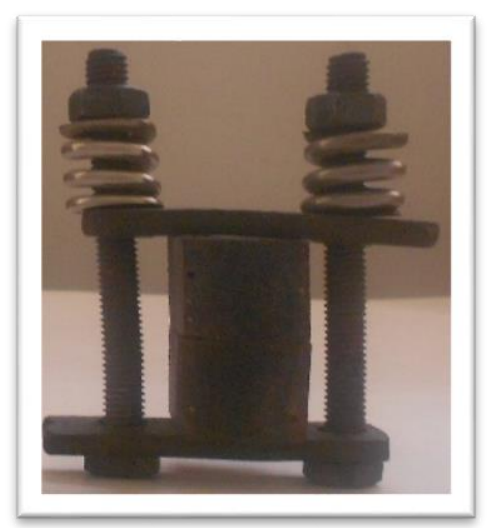

Fig. (1) Photograph of fixture.

The bond strength is the most impotant factor to determine the reliability of the bonded joint. Shear test is the most ideal test to evalute the bond strength [8]. Tensile machine type Instron [WDW-200E] class1, made in China, with $200 \mathrm{KN}$ pressing load was used for this purpose, Fig. (2). The applied load was generated at speed of $1 \mathrm{~mm} / \mathrm{min}$. Generally the failure for all specimen has one feature, failure at the gray cast iron joint interface. The actual bonded area was calculated by using a computer package AutoCad 2006, shear strength values were predicted for each bonded sample. 

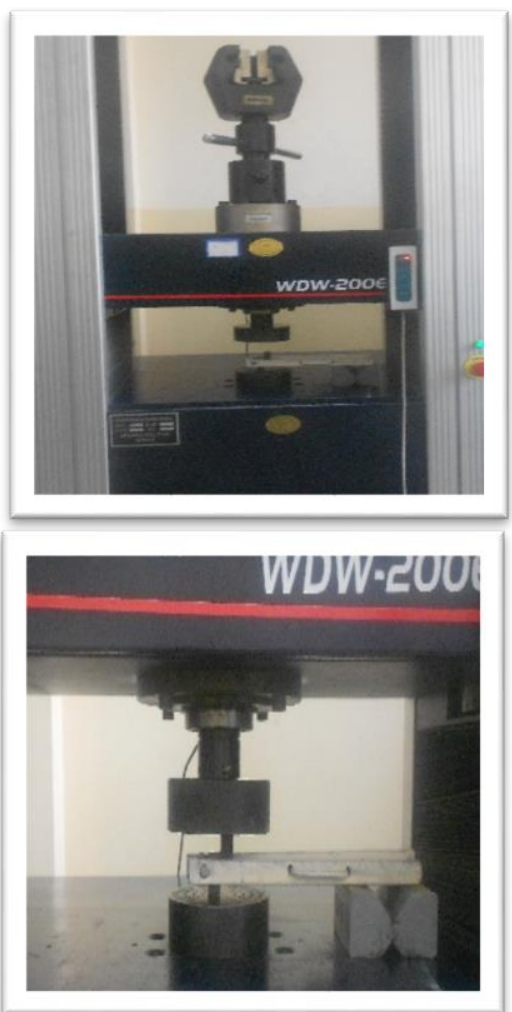

Fig. (2) Instron machine utilized to determine shear strength, with suitable fixture.

Certain stainless steel fixtures were designed to constrain the applied shear stress on the joint, the fixture with dimensions $26 \mathrm{~cm}$ $x 1.5 \mathrm{~cm} \times 4 \mathrm{~cm}$ is shown in Fig.(3).

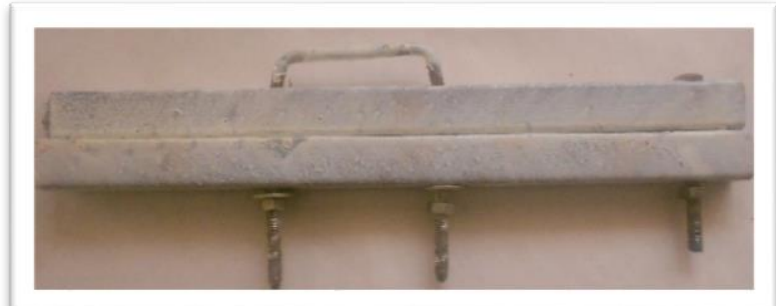

(a)

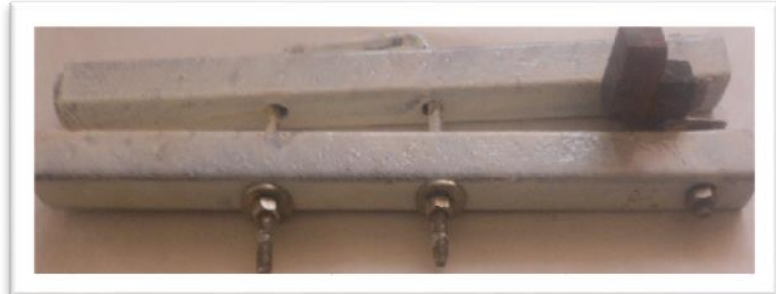

(b)

Fig. (3) Shear test fixture to constrain the applied load, (a) befor assemply (b) after assembly.
Commonly it is difficult to calculate the actual bonded area by using the usual calculating procedures to predict the actual shear strength for each bonded sample. AutoCad 2006. Package was adopted for this purpose as mentioned earlier. Fig.(4) shows all steps to select and determine the bonded area and it can be listed as shown below:-to select scale for enlarges or reduces selected area with keeping the properties of the area the same as it was after scaling, then select spline to creats the smooth curve that passes through or near specified points, then draw the zigzag line to surround the contact area. The value of contact area can be then predicted.

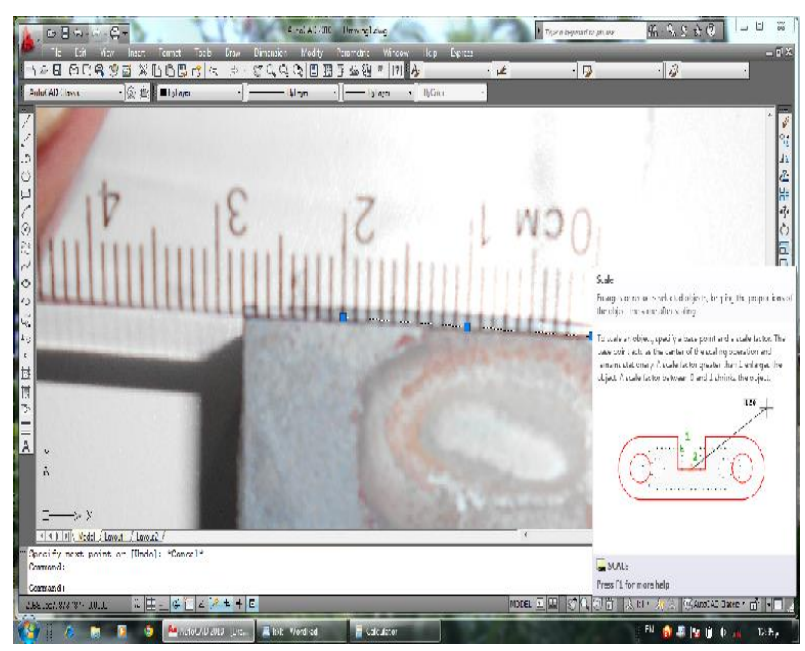

(a)

Fig. (4) Measuring of the bonded area by using AutoCAD program, (a) select the scale (b) select the spline.

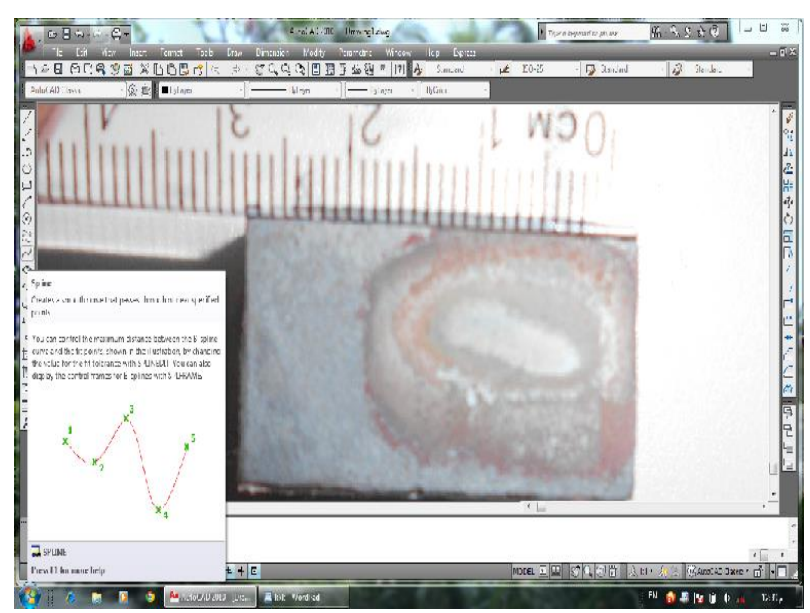

\section{Results and Discussion}

Shear tests were performed on gray cast iron joint which were chosen according to elastic and thermal properties of the materials being bonded. Results shows that the shear 
strength increases with increasing temperature due to dissolved graphite, graphite diameters were decreased at elevated temperatures compared with lower temperatures [3,9]. Table (2) illustrates the solid state bonding parameters of shear tested joints, bonding temperature, pressing load, and holding time.

Table (2)

Solid state bonding parameters.

(a) Time (15 min)

\begin{tabular}{|c|c||c||c||c|}
\hline $\begin{array}{c}\text { Temperature } \\
\left({ }^{\circ} \mathbf{C}\right)\end{array}$ & $\begin{array}{c}\text { Pressing } \\
\text { load } \\
(\text { ton })\end{array}$ & $\begin{array}{c}\text { Load } \\
(\mathbf{K N})\end{array}$ & $\begin{array}{c}\text { Area } \\
(\mathbf{m m})\end{array}$ & $\begin{array}{c}\text { Shear } \\
\text { Strength } \\
(\mathbf{M P a})\end{array}$ \\
\hline \hline \multirow{2}{*}{700} & 1 & 1.517 & 33.9 & 45.8 \\
\cline { 2 - 5 } & 2 & 1.402 & 20.4 & 46 \\
\hline \hline \multirow{2}{*}{750} & 1 & 1.428 & 27.6 & 48.9 \\
\cline { 2 - 5 } & 2 & 1.52 & 27 & 51.3 \\
\hline \hline \multirow{2}{*}{800} & 1 & 1.421 & 22.4 & 55.2 \\
\cline { 2 - 5 } & 2 & 2.38 & 36.3 & 63 \\
\hline \multirow{2}{*}{850} & 1 & 1.517 & 21.3 & 67.6 \\
\cline { 2 - 5 } & 2 & 2.43 & 33.6 & 72 \\
\hline \multirow{2}{*}{900} & 1 & 2.414 & 34.3 & 74 \\
\cline { 2 - 5 } & 2 & 3.152 & 39.5 & 75 \\
\hline \hline
\end{tabular}

(b) Time 30 (min).

\begin{tabular}{||c||c|c|c||c||}
\hline $\begin{array}{c}\text { Temperature } \\
\left({ }^{\circ} \mathbf{C}\right)\end{array}$ & $\begin{array}{c}\text { Pressing } \\
\text { Load } \\
(\text { ton })\end{array}$ & $\begin{array}{c}\text { Load } \\
(\mathrm{KN})\end{array}$ & $\begin{array}{c}\text { Area } \\
(\mathbf{m m})\end{array}$ & $\begin{array}{c}\text { Shear } \\
\text { Strength } \\
(\mathbf{M P a})\end{array}$ \\
\hline \hline \multirow{2}{*}{700} & 1 & 2.44 & 30.3 & 63.884 \\
\cline { 2 - 5 } & 2 & 1.076 & 22.3 & 48 \\
\hline \hline \multirow{2}{*}{750} & 1 & 1.23 & 9.6 & 50.4 \\
\cline { 2 - 5 } & 2 & 1.186 & 22.5 & 55 \\
\hline \multirow{2}{*}{800} & 1 & 1.48 & 14.6 & 84 \\
\cline { 2 - 5 } & 2 & 2.003 & 29.7 & 67.6 \\
\hline \hline \multirow{2}{*}{850} & 1 & 3.344 & 28.5 & 117.3 \\
\cline { 2 - 5 } & 2 & 1.67 & 19.6 & 79 \\
\hline \multirow{2}{*}{900} & 1 & 2.429 & 15.4 & 155.7 \\
\cline { 2 - 5 } & 2 & 2.378 & 23.6 & 98 \\
\hline
\end{tabular}

(c) Time $60(\mathrm{~min})$

\begin{tabular}{|c||c||c||c||c||}
\hline $\begin{array}{c}\text { Temperature } \\
\left({ }^{\circ} \mathbf{C}\right)\end{array}$ & $\begin{array}{c}\text { Pressing } \\
\text { Load } \\
(\text { ton })\end{array}$ & $\begin{array}{c}\text { Load } \\
(\mathrm{KN})\end{array}$ & $\begin{array}{c}\text { Area } \\
(\mathbf{m m})\end{array}$ & $\begin{array}{c}\text { Shear } \\
\text { Strength } \\
(\mathbf{M P a})\end{array}$ \\
\hline \hline \multirow{2}{*}{700} & 1 & 1.42 & 21.8 & 65 \\
\cline { 2 - 5 } & 2 & 1.18 & 22.2 & 49 \\
\hline \multirow{2}{*}{750} & 1 & 2.29 & 20.4 & 112 \\
\cline { 2 - 5 } & 2 & 1.543 & 20.7 & 63 \\
\hline \multirow{2}{*}{800} & 1 & 3.152 & 26.2 & 119.8 \\
\hline \multirow{2}{*}{850} & 2 & 2.34 & 28 & 69 \\
\cline { 2 - 5 } & 1 & 1.93 & 16.4 & 116.6 \\
\hline \multirow{2}{*}{900} & 2 & 2.37 & 32.3 & 78 \\
\cline { 2 - 5 } & 2 & 2.37 & 19.9 & 119.4 \\
\hline \hline
\end{tabular}

Results are presented in Fig.(5) shows increase in shear values at holding time 15 min, under pressing load 1 and 2 ton for all experimental bonding temperatures, this can be due to effect and mutual diffusion of alloying elements at the interface [9].

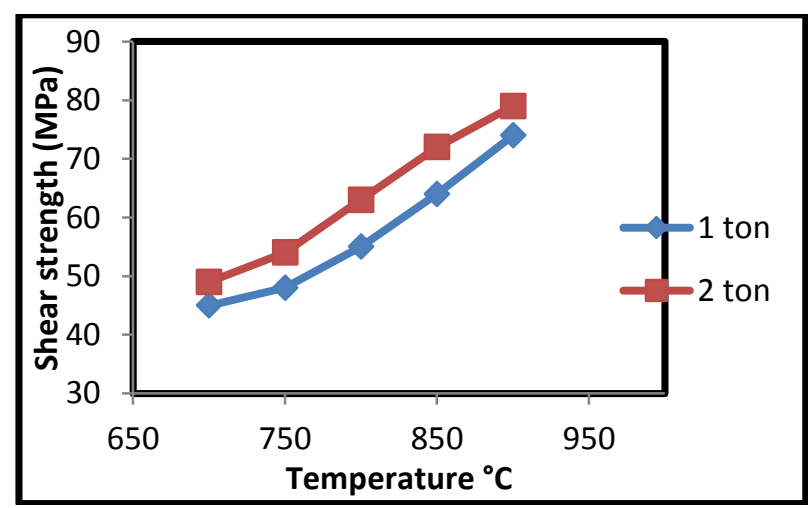

Fig. (5) Shear strength-temperature relationship for gray cast iron joint at 15 min, 1 and 2 ton.

Fig.(6), observed the shear strength increases with increasing temperature. Bonding temperature brings about an improvement in bond strength, but to a certain limit only. Any further rise in temperature will impair the strength owing to a grain growth [1]. 


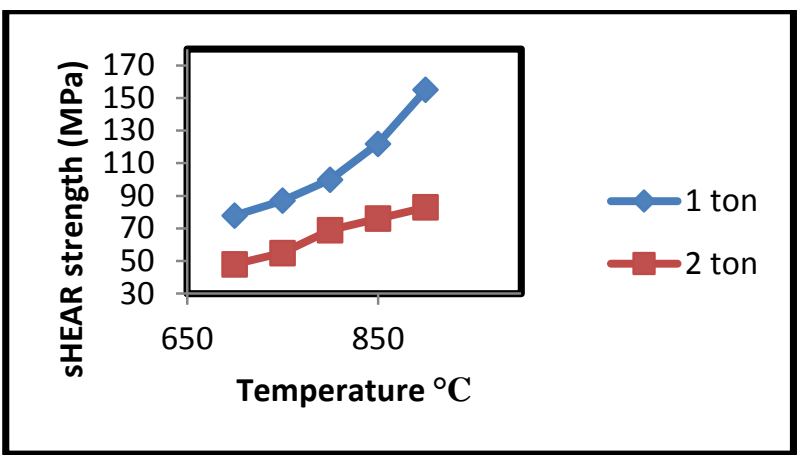

Fig. (6) Shear strength-temperature relationship for gray cast iron joint at $30 \mathrm{~min}$, 1 and 2 ton.

The results that are observed from the Fig.(7) indicate that the shear strength increases with increasing temperature, but this value is lower compared with the values seen at pressing load 1 and 2 ton for holding time 60 min, which are well agreed with Ref. [10]. The pressing load is raised, the asperities are crushed and the area of actual contact increases. Thus, there is improvement in the bond strength as the bonding pressure is raised and more is mainly attributable to the increase in the area of actual contactareas between the mating surfaces. Pressing load will raise bond strength up to a certain value; which is well agreed with Ref. [1]. Heat treatment allows changing the microstructure and properties of investigated cast iron within wide range mentioned in Ref. and as [11].

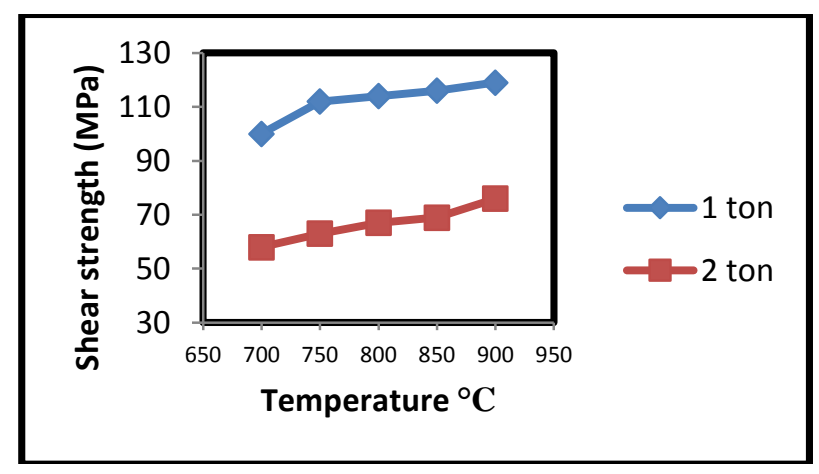

Fig. (7) Shear strength-temperature relationship for gray cast iron joint at $60 \mathrm{~min}$, 1 and 2 ton.

Fig.(8) shows the microstructures of the bond regions for a typical bonded specimens for 30 and $60 \mathrm{~min}$ at 800,850 and $900^{\circ} \mathrm{C}$ under 1 ton. Fig.(8) which shows a good bonding along the interface of the bondedcouples and the interface is free from microvoids andmicrocracks. The diffused Carbon from gray cast iron to interface raises carbide formation in interface zone, the width of this region increases with increasing bonding temperature [12]. Fig.(8a) shows the microstructure of solid state bonded specimenat bonding temperature of $800^{\circ} \mathrm{C}$ under pressure of 1 ton for holding time of 30 min, undissolved graphite flakeof solid state bonded couple. This temperature is not enough for dissolving graphite flake [1]. Carbide formation occurred as a result of carbon diffusion in the graycast iron matrix and then the carbon migrated into the interface. Fig.(8b) shows partially dissolved graphite flake for specimens bonded at $800^{\circ} \mathrm{C}$ under pressure of 1 ton for 60 min holding time. Fig.(8c) shows dissolved graphite flake at the inside of cast iron for specimens bonded at $850^{\circ} \mathrm{C}$ under pressing load 1 ton for holding time of 30 min. Fig.(8d) also shows all dissolved graphite flakes at $900^{\circ} \mathrm{C}$ under pressing load of 1 ton for holding time of 30 min. Silicon in cast iron has a graphitizing effect. Therefore, graphite flakes does not dissolve significantly. But as the temperature increased, at $850,900^{\circ} \mathrm{C}$ the more Si diffused to interface the more graphite dissolved and at $900^{\circ} \mathrm{C}$ all graphite dissolved in the cast iron as clearly seen from Fig.(8d), at $900^{\circ} \mathrm{C}$ under pressing load of 1 ton for holding time of 30 $\mathrm{min}$, completely diffused $\mathrm{Si}$ region is followed by a region with dissolved graphite flakes [1]. Holding time plays a significant role in improving bond strength, the increase in holding time has a positive effect up to a certain limit. This agrees with the result previous ref. [13]. Width of interface region increases with increasing bonding temperature and increasing holding time [3], as shown in Fig. (8a) the interface region bonded at $800^{\circ} \mathrm{C}$ under holding temperature 30 min under 1 ton is thinner than the interface were seen in Fig.(8c) at same holding time but at different bonding temperature at $850^{\circ} \mathrm{C}$ under same pressing load of 1 ton, the quality of the coalescence atinterfaces increases at elevated temperatures [9]. 


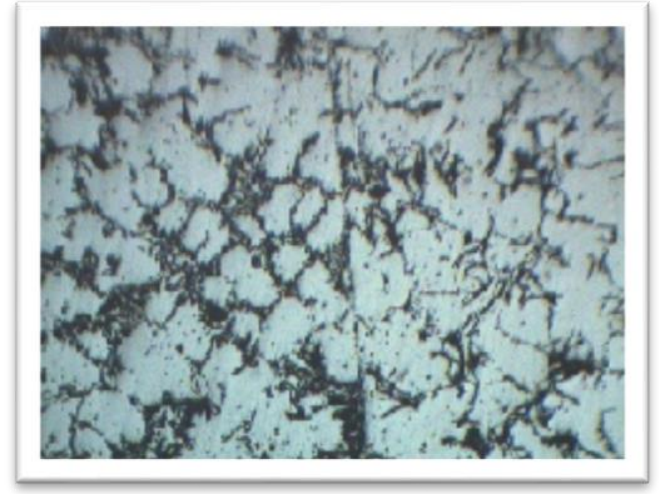

(a)

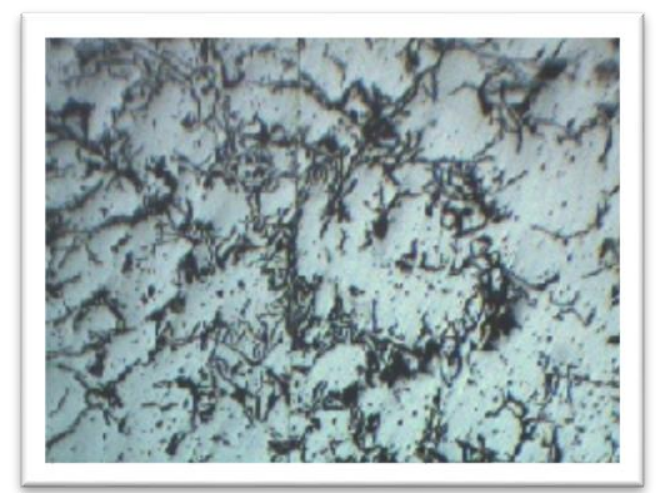

(b)

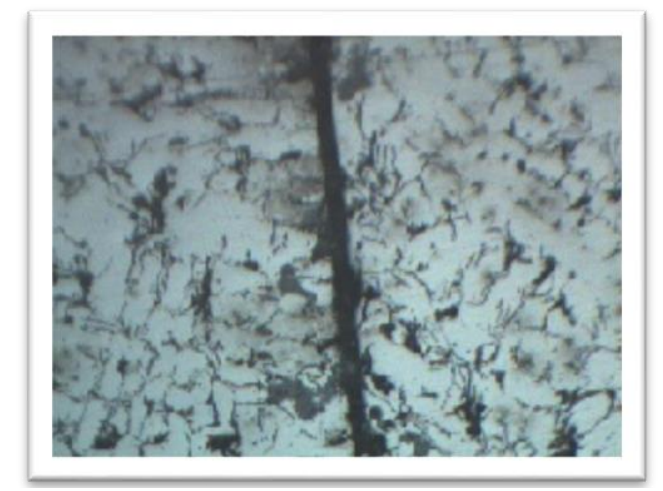

(c)

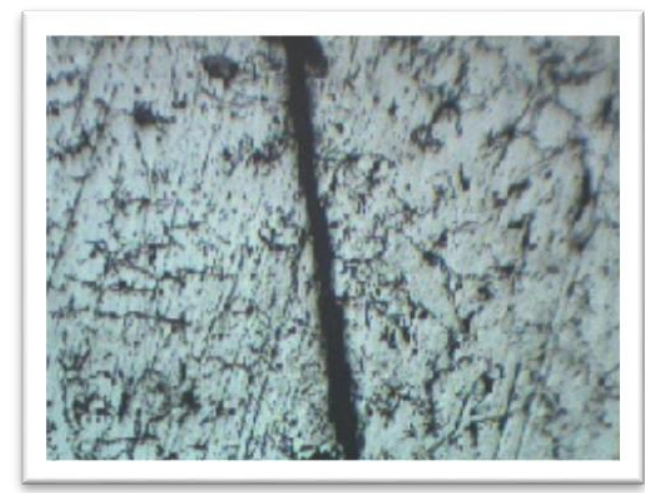

(d)

Fig. (8) Microstructure of the bond interface of the specimens for test parameters of (a) $800^{\circ} \mathrm{C}, 30 \mathrm{~min}, 1 \mathrm{ton},(\mathrm{b}) 800^{\circ} \mathrm{C}, 60 \mathrm{~min}$, lton, (c) $850^{\circ} \mathrm{C}, 30 \mathrm{~min}, 1 \mathrm{ton},(\mathrm{d}) 900^{\circ} \mathrm{C}, 30$ min, 1ton.

\section{Conclusions}

1.In this research, the gray cast iron/ gray cast iron couple are bonded successfully.

2.The high temperature 850, $900{ }^{\circ} \mathrm{C}$ increases joint strength for shear strength test.

3.Increasing the bonding time increases the strength of the joint.

4. The pressing load has slight effect on the shear strength.

5.Optimum shear strength of gray cast iron/ gray cast iron joint is (155.7 $\mathrm{MPa})$ at $900^{\circ} \mathrm{C}$ under pressure 1 ton for $30 \mathrm{~min}$ holding time.

6.Phases such as iron carbide $\left(\mathrm{Fe}_{3} \mathrm{C}\right)$ are formed in the gray cast iron/ gray cast iron interface.

7.The diffusion of $\mathrm{C}$ from graphite in gray cast iron to interface increases with increasing temperature especially at 850 , $900^{\circ} \mathrm{C}$.

8.The quality of the coalescence at interfaces increases at elevated temperatures under confined and experimented conditions. On average, the best strength were observed in specimen bonded at $850,900^{\circ} \mathrm{C}$.

\section{References}

[1]. Kazakov N. F. "Diffusion bonding of materials", Mir Publishers, Moscow, 1985.

[2].Klaasen H., Kübarsepp J., Laansoo A., Viljus M., "Reliability of dual compounds "carbide composite+steel" produced by diffusion welding" , J. of Inter. Refrac. Metals and Hard Materials, Vol. 28, No. 5, PP. 580-586, 2010.

[3]. Kurt B., Orhan N., Hascalık A., "Effect of high heating and cooling rate on interface of diffusionbonded gray cast iron to medium carbon steel", J. of Mater. and Design, Vol. 28, PP. 2229-2233, 2007.

[4].Wang Y., Luo G., Zhang J., Shen Q., Zhang L., "Microstructure and mechanical properties of diffusion-bonded $\mathrm{Mg}-\mathrm{Al}$ joints using silver film as interlayer" J. of Mater. Scien. And Engin., Vol. 559, No. 1, PP. 868-874, 2013.

[5].Kemal Aydin K., Yakup Kaya Y., Nizamettin Kahraman N., "Experimental study of diffusion welding/ bonding of 
titanium to copper" J. of Materials and Design, Vol. 37, PP. 356-368, 2012.

[6].Ozdemir N., Aksoy M. and Orhan N., "Effect of graphite shape in vacuum-free diffusion bonding of nodular cast iron with gray cast iron", J. of Mater. Proce. Techn. Vol. 141, PP. 228-233, 2003.

[7]. Metals Handbook, Vol. 1, ASM, Properties and selection: Iron, Steels and high performance alloys, 1990.

[8].Scoloro J. M., and Valle A.L., "Bonding ceramic to metal: A Comparison using shear tests", Rev. Fob. Vol. 16, No. 1, PP 57-62, 2002.

[9].Kolukisa S., "The effect of the welding temperature on the weldability in diffusion welding of martensitic (AISI 420) stainless steel with ductile (spheroidal graphitenodular) cast iron," J. of Mater. Proce. Tech.Vol.186, PP. 33-36, 2007.

[10]. Wen Kanga Sh., Tang Chena Y., and Pen Liu H., "Brazing diffusion bonding of micro-nickel cylindersand SUS-316 stainless steel", J. of Mater. Proce. Techno., Vol.168, 286-290, 2005.

[11]. Krawczyk J., Pacyna J., "The Influence of Microstructure of Mottled Cast Iron for Mill Rolls on Its Properties", Vol. 5, PP. 19-21, 2009.

[12]. R. Jiangwei, L. Yajiany, and F. Tao, "Microstructure characteristics in the interface zone of $\mathrm{Ti} / \mathrm{Al}$ diffusion bonding", J. of Mater, Vol.56, No.5, PP.647-652. 2002.

[13]. Nishada T., Sueyoshi H., "Solid State Bonding of Graphite to Inconel 718", J. Japan Ins. Metals, Vol. 65, No.4, PP. 303309, 2001.
بتضمن البحث دراسة الربط الانتشاري لحديد الزهر

الرمادي بالظروف الجوية باستخدام طرق تسخن مختلفة

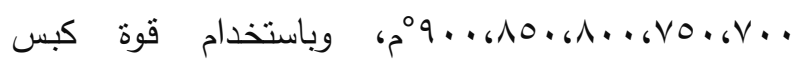

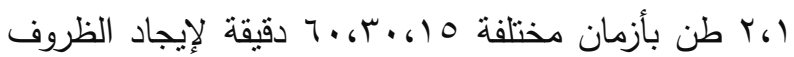

العملية المناسبه التي تؤثز على متانة الربط. قيمت منانة

الربط باستخدام فحص القص وأظهرت النتائج إن متانة الربط

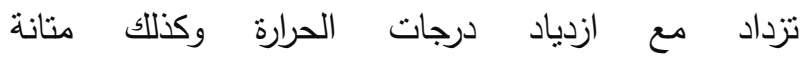

الربط تزداد مع ازدياد الوقت. استخدم برنامج

(Auto Cad 2006) لحساب مساحه التماس. لوحظ عند

استخدام غاز الاركون انه لم تتكون وصله ربط بسبب

الاكسده. بعد استبيان النتائج التي تم الحصول عليها من

الدراسة ألمختبريه تبين إن الوصلات المربوطة وجدت مقاومة قص قصوى تساوي 100,V ميكاباسكال عند ربطها في درجه حرارة 900॰م تحت قوة كبس ا طن ولفترة تسخين · ب دقيقة. وتبين من اختبارات الفحص المجهري تكون أطواركاربيدية (Carbides) 